\title{
Antimicrobial potential of actinobacteria isolated from the rhizosphere of the Caatinga biome plant Caesalpinia pyramidalis Tul.
}

\author{
G.R. Silva-Lacerda, R.C.F. Santana, M.C.V. Vicalvi-Costa, E.G. Solidônio \\ K.X.F.R. Sena, G.M.S. Lima and J.M. Araújo \\ Laboratório de Coleção de Microrganismos, Departamento de Antibióticos, \\ Universidade Federal de Pernambuco, Recife, PE, Brasil \\ Corresponding author: G.M.S. Lima \\ E-mail: gmslima@yahoo.com.br \\ Genet. Mol. Res. 15 (1): gmr.15017488 \\ Received August 20, 2015 \\ Accepted November 26, 2015 \\ Published March 4, 2016 \\ DOI http://dx.doi.org/10.4238/gmr.15017488
}

ABSTRACT. Actinobacteria are known to produce various secondary metabolites having antibiotic effects. This study assessed the antimicrobial potential of actinobacteria isolated from the rhizosphere of Caesalpinia pyramidalis Tul. from the Caatinga biome. Sixty-eight actinobacteria isolates were evaluated for antimicrobial activity against different microorganisms by disk diffusion and submerged fermentation, using different culture media, followed by determination of minimum inhibitory concentration (MIC) and chemical prospecting of the crude extract. Of the isolates studied, $52.9 \%$ of those isolated at $37^{\circ} \mathrm{C}$ and $47.05 \%$ of those isolated at $45^{\circ} \mathrm{C}$ had activity against Bacillus subtilis, Staphylococcus aureus, methicillin-resistant $S$. aureus (MRSA), Fusarium moniliforme, and Candida albicans. When compared with others actinobacteria, the isolate C1.129 stood out with better activity and was identified by 16S rDNA gene analysis as Streptomyces parvulus. The crude ethanol extract showed an MIC of $0.97 \mu \mathrm{g} / \mathrm{mL}$ for MRSA and B. subtilis, while the ethyl acetate extract showed MIC of $3.9 \mu \mathrm{g} / \mathrm{mL}$ for $S$. aureus and MRSA, showing the greatest potential among the metabolites produced. Chemical prospecting revealed 
the presence of mono/sesquiterpenes, proanthocyanidin, triterpenes, and steroids in both crude extracts. This study evaluates S. parvulus activity against multi-resistant microorganisms such as MRSA. Thus, it proves that low-fertility soil, as is found in the Caatinga, may contain important microorganisms for the development of new antimicrobial drugs.

Key words: Streptomyces; Bioactive compounds; Antimicrobial activity

\section{INTRODUCTION}

The Caatinga biome is located in the northeast of Brazil, covers eight northeastern states and part of Minas Gerais, and is a biological heritage site in the region that exists nowhere else in the world. It is the least protected of all Brazilian biomes, and has been subjected to environmental deterioration. While the Caatinga biome is characterized by its wide species diversity, biodiversity conservation in the region faces major challenges (Gorlach-Lira and Coutinho, 2007). The endemic plant Caesalpinia pyramidalis Tul. is one of these diverse species found here. It is used for various purposes, including the treatment of diarrheal processes and dysentery, as well as of respiratory infections.

The rhizosphere is a soil region strongly influenced by plant roots, and has maximum microbial activity and a large microbial diversity, which in most cases is enriched with the byproducts of plant metabolism. Bacteria, fungi, actinobacteria, and plants live in a constant process of symbiosis (Melo and Azevedo, 2008; Berg and Smalla, 2009).

The study of microorganisms from the rhizosphere plants of the Caatinga is extremely important, since they are a means by which low-fertility soil can become a powerful source of biotechnologically important metabolites. The search for products effective against multi-drug resistant bacteria pathogenic to humans is an important goal. The rapid and aggressive development of antimicrobial-resistant bacterial species has motivated scientists to develop novel biomolecules. Microorganisms of the rhizosphere - in particular the actinobacteria - are a promising source of new antibiotics and are of great interest to the pharmaceutical industry and biotechnology (Higginbotham and Murphy, 2010; Choi et al., 2012).

The actinobacteria constitute an important group of bacteria commonly isolated from the rhizosphere. They are Gram-positive and are known to produce several types of antibiotics with practical applications in industry, agriculture, medicine, and veterinary science. The genus Streptomyces is the best known among the actinobacteria, and includes over 3000 identified species (Goodfellow et al., 2012). They are in greater abundance in the soil, but may also occur in various other environments. These filamentous bacteria are aerobic and synthesize volatile compounds, such as geosmin, which gives soil its characteristic "wet earth" odor. Streptomyces sp are very valuable, as they produce several commercial antibiotics, including streptomycin (Vasconcellos et al., 2010; Madigan et al., 2012). Given this, the aim of the present study was to evaluate the antimicrobial activity of actinobacteria isolated from the rhizosphere of the plant Caesalpinia pyramidalis Tul. from the Caatinga biome.

\section{MATERIAL AND METHODS}

\section{Isolation of actinobacteria}

Isolations were performed from $10 \mathrm{~g}$ rhizosphere in $90 \mathrm{~mL}$ PBS buffer. The sample was 
pretreated by homogenization in vortex for $20 \mathrm{~min}$ and by placing in a $50^{\circ} \mathrm{C}$ water bath for $15 \mathrm{~min}$. Samples were serially diluted from $10^{-3}$ to $10^{-5}$ in saline solution, and $0.1 \mathrm{~mL}$ of each dilution was inoculated into AY modified media (AYM) (Nomomura and Ohara 1969a); MC (Nomomura and Ohara, 1969b), and ISP-4 (Shirling and Gottlieb, 1966). The plates were incubated in a greenhouse B.O.D. (biochemical oxygen demand) at $37^{\circ} \mathrm{C}$ and $45^{\circ} \mathrm{C}$ for 20 days.

\section{Determination of antimicrobial activity}

\section{Preliminary assay}

Seeding of actinobacteria was performed following the method of Ichikawa et al. (1971). Strains were cultivated in a carpet at $37^{\circ} \mathrm{C}$ and $45^{\circ} \mathrm{C}$. After $120 \mathrm{~h}$, an agar block diffusion assay was performed using test microorganisms strains from the Microorganism Culture Collection of Departamento de Antibióticos, Universidade Federal de Pernambuco (UFPEDA). Species included for testing were: Fusarium moniliforme UFPEDA-2456; Malassezia furfur UFPEDA-1320; Candida albicans UFPEDA-1007; Bacillus subtilis UFPEDA-86; Staphylococcus aureus UFPEDA-02; methicillin-resistant S. aureus (MRSA) UFPEDA-700; Escherichia coli UFPEDA-224; Klebsiella pneumoniae UFPEDA-416; and Pseudomonas aeruginosa UFPEDA-396 (Vasconcelos et al., 2015).

\section{Secondary assay}

The actinobacteria was cultivated in the media ISP-4, modified AYM, M1, and MPE (Kawamura et al., 1976) and stirred at $180 \mathrm{rpm}$ for $120 \mathrm{~h}$. After this period, 10\% (v/v) were transferred to Erlenmeyer flasks containing $50 \mathrm{~mL}$ medium. Every $24 \mathrm{~h}$, a 1-mL aliquot was taken to evaluate the dry weight, antimicrobial activity, and $\mathrm{pH}$. For evaluating the antimicrobial activity of secondary metabolites, a disc diffusion test was performed. Fifty-microliter aliquots fermented liquid were placed on Mueller Hinton $(\mathrm{MH})$ plates containing the test microorganisms strains and incubated at $37^{\circ} \mathrm{C}$ for $24 \mathrm{~h}$. The disc diffusion test was performed in triplicate and the results were determined through the arithmetic average of the inhibition zone diameters in millimeters (CLSI, 2014).

\section{Extraction of bioactive metabolites}

Streptomyces $\mathrm{C} 1.129$ was cultivated in the $\mathrm{M} 1$ medium at $37^{\circ} \mathrm{C}$ for $96 \mathrm{~h}$ at $180 \mathrm{rpm}$. Extraction of metabolites from the cell mass and liquid was then performed. The cell mass was treated with acetone, ethanol, and pure methanol at $\mathrm{pH}$ 2.0, 7.0, and 9.0, and for the metabolic liquid we used ethyl acetate, chloroform, and pure petroleum ether at the same $\mathrm{pH}$ values mentioned above. The $\mathrm{pH}$ was then adjusted to 7.0, and the antimicrobial activity was assessed using the disc diffusion test (Lyra et al, 1964; CLSI, 2014)

\section{Determination of minimum inhibitory concentration (MIC)}

Antimicrobial activity was determined by microdilution in multiwell plates, according to the methods prescribed by the Clinical and Laboratory Standards Institute (CLSI, 2014). MH broth was distributed in wells and extract was added at concentrations ranging from 1000 to $3.9 \mu \mathrm{g} / \mathrm{mL}$. Then, standardized microbial inoculum, containing $1.5 \times 10^{8} \mathrm{~S}$. aureus UFPEDA-02, MRSA UFPEDA-700, and B. subtilis UFPEDA-86, was added. Microplates were cultured at $37^{\circ} \mathrm{C}$ for 18 to 24 
h. Ethanol and ethyl acetate extracts were tested for activity against Gram-positive bacteria, using as a standard control oxacillin, which has an MIC of $4 \mu \mathrm{g} / \mathrm{mL}$ for $S$. aureus. Microplates were then stained with $0.01 \%$ resazurin and incubated for 1 to $3 \mathrm{~h}$ to observe color changes in the wells (blue to pink). The bactericidal minimum concentration was determined by establishing subculture wells on Petri dishes containing the solid medium $\mathrm{MH}$ and incubating at $37^{\circ} \mathrm{C}$ for $24 \mathrm{~h}$.

\section{Prospection chemical of the extracts}

Ethanolic and ethyl acetate crude extracts were analyzed by thin-layer chromatography (TLC) in aluminum TLC sheets containing silica gel 60 F254 (Merck). For the identification of classes of secondary metabolites, various mobile phases were used and specific revealing (Robertson et al., 1956; Metz, 1961; Sharma and Darwra, 1991; Wagner and Bladt, 1996; Harbone, 1998).

\section{Bioautography}

The antimicrobial fraction was characterized using the TCL bioautography technique described by Scher et al. (2004). The crude extract of biomass and metabolic liquid was applied to a silica gel plate 60 F254 (Merck), and the chromatographic run performed using the solvent system $\mathrm{CHCl}_{3}: \mathrm{MeOH}(9: 1 \mathrm{v} / \mathrm{v})$. Organic revelation was performed using $\mathrm{MH}$ culture medium inoculated with a suspension of $S$. aureus (UFPEDA 02) with a density in the range of 0.5 by the MacFarland scale $(1.5 \mathrm{UFC} / \mathrm{mL})$ and incubated at $37^{\circ} \mathrm{C}$ for $24 \mathrm{~h}$. Revelation was conducted with an aqueous solution of 2,3,5-triphenyltetrazolium chloride $(20 \mathrm{mg} / \mathrm{mL})$ and maintained at $37^{\circ} \mathrm{C}$ for 2 to $4 \mathrm{~h}$.

\section{Classical taxonomic characterization}

Micromorphological analysis was performed using the method followed by Shirling and Gottlieb (1966). Actinobacteria were inoculated as a wide streak on ISP-4 culture medium; coverslips were inserted at a $45^{\circ}$ inclination on the streak to induce growth of aerial mycelia on the coverslip. The culture medium was then incubated at $37^{\circ} \mathrm{C}$ for 5 to 10 days, after which the coverslip was removed to observe the formation of spore-sporophore chains using an optical microscope with a 40X objective (Medilux, MDL-150-BAI).

The actinobacterial cell wall was studied by assessing isomers of diaminopimelic acid (DAP), LL-diaminopimelic acid or meso-diaminopimelic acid, according to the methodology of Staneck and Roberts (1974). The bacterial cell wall was hydrolyzed and evaluated by TLC with a mobile phase consisting of methanol:water:hydrochloric acid $6 \mathrm{~N}$ :pyridine $(80: 26: 4: 10 \mathrm{v} / \mathrm{v})$ and fixed-layer cellulose plates Merck No. 5716, 20 × 20 (Merck Millipore Corporation, Darmstadt, Germany). Streptomyces regensis (UFPEDA-3053) and Nocardia asteroides (UFPEDA-3503), which show LL-DAP and Meso-DAP isomers, respectively, were used as standards. Visualization was performed using $0.2 \%$ ninhydrin and heating at $100^{\circ} \mathrm{C}$ for $5 \mathrm{~min}$ to visualize the isomers.

\section{Molecular characterization}

DNA was extracted from the bacterial strain C1.129 using culture grown in ISP-2 liquid medium for $16 \mathrm{~h}$ at $37^{\circ} \mathrm{C}$. Subsequently, the sample was centrifuged for $3 \mathrm{~min}$ at $9168 \mathrm{~g}$, and DNA extraction performed using the Wizard genomic DNA purification kit according to the manufacturer instructions (Promega Biotecnologia). The extracted DNA was assessed using electrophoresis on 
an agarose gel, and host $16 \mathrm{~S}$ ribosomal RNA (rRNA) was amplified by polymerase chain reaction (PCR) using universal oligonucleotides.

The reaction mixture, in $25 \mu \mathrm{L}$ final volume, comprised $50 \mathrm{ng}$ DNA; 5 pmol each oligonucleotide (fD1; 5'-AGAGAGTTTGATCCTGGCTCAG-3' and rD1 5'-CGGTGTGTACAAGGCCCGGG GAACG-3'); $200 \mathrm{mM}$ dNTP; $1.5 \mathrm{mM} \mathrm{MgCl}$; $1 \mathrm{X}$ buffer; and $1 \mathrm{U}$ Platinum Taq DNA polymerase (Invitrogen Life Technologies, Carlsbad, CA, USA). Reaction conditions were as follows: 5 min denaturation at $94^{\circ} \mathrm{C} ; 25$ cycles of $1 \mathrm{~min}$ at $94^{\circ} \mathrm{C}, 30 \mathrm{~s}$ at $52^{\circ} \mathrm{C}$, and $2 \mathrm{~min}$ at $72^{\circ} \mathrm{C}$, and a final extension of $10 \mathrm{~min}$ at $72^{\circ} \mathrm{C}$ (Weisburg et al., 1991). The amplified product was analyzed by electrophoresis on a $1.2 \%$ agarose $(\mathrm{w} / \mathrm{v}) \mathrm{gel}$, and the sample sequenced by Macrogen (Seoul, Korea). This sequence was compared with those in GenBank, using the BLAST software from the National Center for Biotechnology Information (www.ncbi.nlm.nih.gov). Sequence alignment was performed using the Clustal software (www.ebi.ac.uk/tools/msa/clustaw2), and phylogenetic tree construction was carried out using Mega 5.5. Topology assessed by bootstrap analysis (1000 resamplings).

\section{Statistical analysis}

Statistical analysis was performed by one-way analysis of variance (ANOVA) with a TukeyKramer test (Sokal \& Rohlf, 1995), using Excel 2010 (Microsoft ${ }^{\oplus}$ Office) software and Minitab version $15\left(\right.$ Minitab $\left.^{\circledR}\right)$.

\section{RESULTS}

\section{Isolation of actinobacteria}

Sixty-eight strains of actinobacteria were isolated from the rhizosphere of $C$. pyramidalis Tul. from the Caatinga biome. Of these, $36(52.9 \%)$ were isolated at $37^{\circ} \mathrm{C}$ and $32(47.05 \%)$ at $45^{\circ} \mathrm{C}$. The culture medium with the largest number of colonies was $\mathrm{MC}$, which yielded $60.3 \%$ of the isolates, followed by ISP-4 (23.5\%) and AYM $(16.2 \%)$ at $37^{\circ} \mathrm{C}$ (Figure $\left.1 \mathrm{~A}\right)$. The majority of actinobacteria was isolated in $\mathrm{MC}$ medium (Figure 1B).
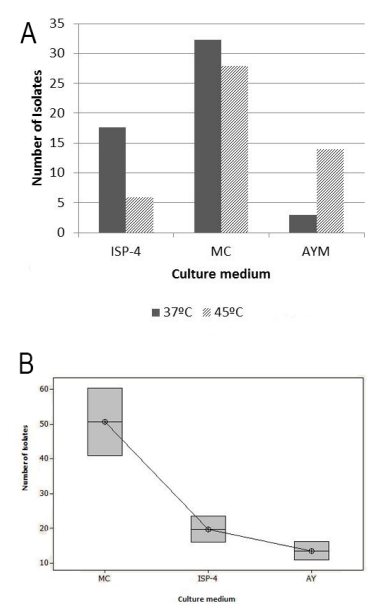

Figure 1. A. Isolation of actinobacteria in different culture media (MC, ISP-4 and AYM) and at different temperatures $\left(37^{\circ}\right.$ and $\left.45^{\circ} \mathrm{C}\right)$. B. Statistical analysis comparing isolation of actinobacteria in various culture media. 


\section{Taxonomic characterization}

Micromorphology of the 68 isolates showed spore chains spiral-shaped and long, short or verticillate, as reported by Goodfellow et al. (2012).

The evaluation of micromorphology showed that all strains belonging to the genus Streptomyces presented short spiral sporophores, while others showed short chains of straight and slightly curved spores. Despite variations, analysis of LL-DAP confirmed that these isolates belonged to the genus Streptomyces.

\section{Molecular characterization of 16S rRNA}

The amplification product generated from strain C1.129 was 1649 bp in length. Comparison with 16S rDNA in the GenBank database revealed a $98 \%$ similarity to Streptomyces parvulus S2-SC26 (accession No. KP339491.1; Figure 2).

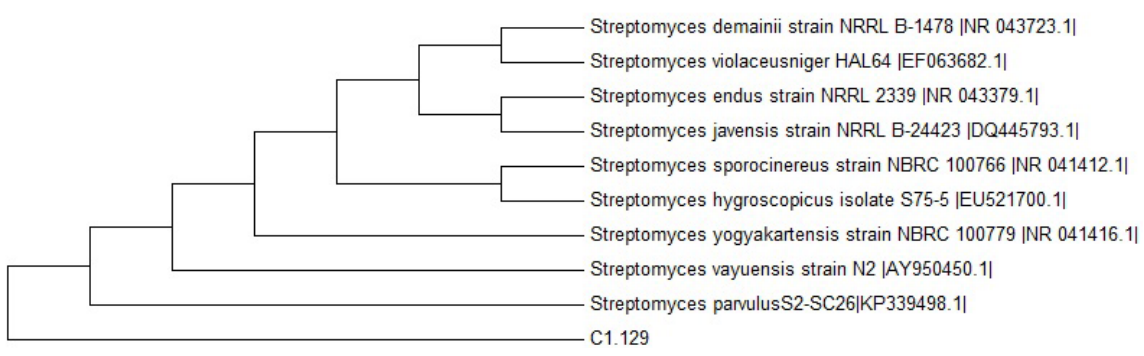

Figure 2. Neighbor-joining tree showing the phylogenetic relationships based on the 16S rRNA gene sequence of the strain C1.129 and the closest species.

\section{Antimicrobial activity}

Evaluation of antimicrobial activity revealed that only $16 \%$ (11) of the 68 isolates showed antimicrobial activity against some of the microorganisms tested; the remaining $84 \%$ (57) showed no antimicrobial activity. Of 36 strains isolated at $37^{\circ} \mathrm{C}, 25 \%(9)$ showed inhibition zones greater than $15 \mathrm{~mm}$, while of 32 strains isolated at $45^{\circ} \mathrm{C}$, only $9.4 \%$ (3) showed similar antimicrobial activity. Strains with antimicrobial activity are presented in Figure 3. The C1.129 strain showed the largest inhibition zones in the primary test for $S$. aureus (UFPEDA-02), B. subtilis (UFPEDA-86), and MRSA (UFPEDA-700); following fermentation for $96 \mathrm{~h}$ in medium M1, halos of up to $28 \mathrm{~mm}$ diameter were observed (Table 1).

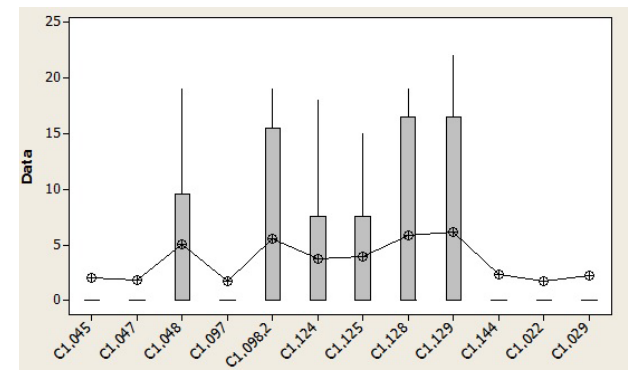

Figure 3. Statistical analysis of relationships between actinobacteria activity against different microorganisms. 


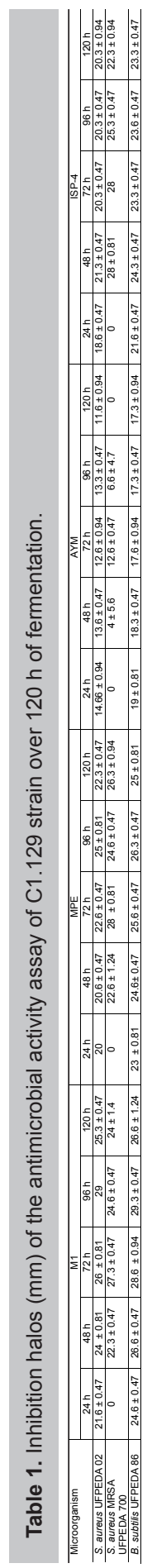




\section{Antibiotic extraction and MIC determination}

The bioactive metabolite of biomass from fermentation of S. parvulus C1.129 (UFPEDA-3408) was extracted using ethanol and showed zones of inhibition above $20 \mathrm{~mm}$ for various microorganisms, such as S. aureus, B. subtilis, and MRSA. The most effective extraction of bioactive compounds from the metabolic liquid was achieved using ethyl acetate, with inhibition zones of up to $28 \mathrm{~mm}$ diameter for to the same microorganisms.

Crude ethanolic extract showed a good antimicrobial activity against the Gram-positive bacteria tested, with MIC values equal to or below $3.9 \mu \mathrm{g} / \mathrm{mL}$. The crude ethyl acetate extract of the liquid metabolic, however, showed MIC values equal to or below $15.62 \mu \mathrm{g} / \mathrm{mL}$. The crude ethanolic extract of biomass showed the best MIC values $(0.97 \mu \mathrm{g} / \mathrm{mL})$ when tested against MRSA (UFPEDA-700) and B. subtilis (UFPEDA-86). The crude ethyl acetate extract of liquid metabolic showed higher MIC values, inhibiting the growth of $S$. aureus (UFPEDA-02) and MRSA (UFPEDA-700) at $3.9 \mu \mathrm{g} / \mathrm{mL}$ (Table 2).

Table 2. Minimum inhibitory concentration of crude extracts of biomass and metabolic net of Streptomyces parvulus C1.129 (UFPEDA-3408) compared to that of other microorganisms.

\begin{tabular}{l|c|c|c|c|c|c}
\hline \multirow{2}{*}{ Microorganisms } & \multicolumn{2}{|c|}{$\begin{array}{c}\text { Crude biomass extract } \\
(\mu \mathrm{g} / \mathrm{mL})\end{array}$} & $\begin{array}{c}\text { Crude extract of liquid metabolic } \\
(\mu \mathrm{g} / \mathrm{mL})\end{array}$ & \multicolumn{3}{c}{ Oxacilin $(\mu \mathrm{g} / \mathrm{mL})$} \\
\cline { 2 - 8 } & MIC & BMC & MIC & BMC & MIC & BMC \\
\hline S. aureus UFPEDA 02 & 3.9 & 15.62 & 3.9 & 15.62 & 0.156 & 0.39 \\
\hline S. aureus MRSA UFPEDA 700 & 0.97 & 1.95 & 3.9 & 31.25 & 256 & 512 \\
\hline B. subtilis UFPEDA 86 & 0.97 & 31.25 & 15.62 & 31.25 & 0.156 & 0.156 \\
\hline
\end{tabular}

$\mathrm{MIC}=$ minimal inhibitory concentration; $\mathrm{BMC}=$ bactericidal minimum concentration .

\section{Bioautography}

Chromatography of the crude extract of biomass revealed two fractions with Rfs of 0.37 and 0.68 , whereas the crude extract of liquid metabolic revealed three fractions with Rfs of 0.2 , 0.37 , and 0.58 (Figure 4). These early results indicate that the fraction of biomass with Rf 0.37 is similar to the fraction of metabolic liquid with the same Rf.

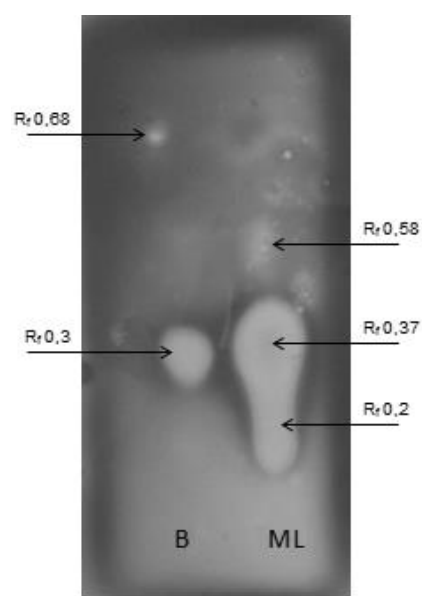

Figure 4. Bioautography of crude extracts of biomass $(B)$ and metabolic liquid (ML) of Streptomyces parvulus. Arrows indicate $R_{f} s$ of bioactive metabolites. 


\section{Chemical prospection of crude extracts}

Aliquots of each sample were analyzed by TLC to identify the class of secondary metabolites. In the crude extract of the biomass, it was possible to verify the presence of reducing sugars, mono/sesquiterpenes, proanthocyanidin, triterpenes, and steroids. In the crude extract of the metabolic liquid, the presence of mono/sesquiterpenes, proanthocyanidin, triterpenes, and steroids was confirmed. However, the reducing sugars are the only metabolites, which differs the substance of biomass from the metabolic liquid, indicating that the antibiotic substance in such extracts could be the same.

\section{DISCUSSION}

Actinobacteria are microorganism that produce numerous secondary metabolites, many of which have already been successfully isolated and some of which have provided important antibiotics with broad medical, veterinary and pharmaceutical applications (Raja and Prabakarana, 2011). Actinobacteria from soil and marine sediments have shown high antimicrobial activity against Gram-positive and -negative bacteria and fungi (Laidi et al., 2008; Zhao et al., 2009).

The predominance of the genus Streptomyces in soil is justified by it is being an actinobacterial group that does not have many nutritional requirements. Other genera may be isolated using more complex culture media with different carbon sources or nitrogen or even at different temperatures than those used in this study. As emphasized by Sanchez and Demain (2002), the carbon source may interfere with growth and the yields of bioactive metabolites. The predominance of the genus Streptomyces in soil has also been reported by researchers worldwide (Velho-Pereira and Kamat, 2011; Manimaran et al., 2015). These findings are in accordance with those of our study.

We observed a high antimicrobial activity against Gram-positive bacteria, which may be due to the cell wall composition of these bacteria being $90 \%$ peptidoglycan, unlike the wall of Gramnegative bacteria, which are much more complex and thus more resistant to antibiotics. Higginbotham and Murphy (2010) evaluated actinobacteria and observed that these exhibited antimicrobial activity against MRSA, with inhibition halos of $22 \mathrm{~mm}$ in diameter (Trabulsi and Alterthum, 2008).

The strain C1.129 showed the best activity against $S$. aureus (UFPEDA-02), MRSA (UFPEDA-700) and B. subtilis (UFPEDA-86) and was used in the secondary assay. This strain was identified as S. parvulus C1.129 and was deposited at the Microorganism Culture Collection of UFPEDA with accession No. UFPEDA-3408.

The isolates that showed no antimicrobial activity on solid medium may still produce antibiotics. The percentage of carbon in the environment and starch concentration are factors that can influence the production of secondary metabolites, and hence it cannot be categorically stated that these isolates do not produce antibiotics. New assays using other culture media and other microorganism tests may detect such antibiotic activity (Matsuura, 2004).

Most antibiotics are produced by genetically distinct species via different pathways, and environmental conditions may therefore have a significant effect on antibiotic production during fermentation. Variable parameters involved in the fermentation process, such as $\mathrm{pH}$, temperature, nutrient composition of the medium, and fermentation time are factors which should be evaluated for characterization of secondary metabolites produced by the strain under study (Pfefferle et al., 2000).

Krishnaveni et al. (2011) have used acetone and chloroform to extract bioactive metabolites from the mycelial mass and the fermented metabolic liquid, respectively, of Streptomyces noursei. In accordance with the results of our studies, crude extracts of the $S$. noursei strain exhib- 
ited antibacterial activity against Gram-positive bacteria, including resistant clinical isolates. Vimal et al. (2009) evaluated the antimicrobial activity of bioactive metabolites from a marine actinobacteria of genus Nocardiopsis. The efficiency of extraction was verified by antimicrobial assays and it was observed that the petroleum ether extract obtained from the isolate showed significant antimicrobial activity against Gram-positive and -negative bacteria; the ethyl acetate extract also showed antifungal activity, and the chloroform extract was observed to be effective against yeast. Thus, ethyl acetate was shown to be an effective solvent for the extraction of bioactive metabolites produced by different actinobacteria, retaining high antimicrobial activity, and studies with such solvents corroborate results of our studies (Arasu et al., 2009; Vimal et al., 2009).

Arasu et al. (2009) evaluated the antimicrobial activity of Streptomyces spp ERI-3, isolated from the rocky soil of the forests of the Western Ghats in India. There, as in this study, microorganisms were observed to produce bioactive metabolites, which could be extracted from the supernatant (metabolic liquid) using ethyl acetate. The extract thus obtained inhibited the growth of $B$. subtilis (MIC $=0.25 \mathrm{mg} / \mathrm{mL})$ and $S$. aureus $(\mathrm{MIC}=0.5$ to $1 \mathrm{mg} / \mathrm{mL}$ ) considerably more than what was observed in this study. Khieu et al. (2015) purified compounds from S. parvulus, and one of them presented an MIC of $62.5 \mu \mathrm{g} / \mathrm{mL}$ for MRSA, lower than the values observed in our study. These studies corroborate our findings, and also report the action of bioactive metabolites of Streptomyces against Gram-positive and multidrug-resistant bacteria.

It is noteworthy that bioautography is effective for the detection of antimicrobials present in the extracts, which generally occur as complex mixtures of compounds, albeit in small quantities. However, the technique restricts the identification of the fraction that has antimicrobial activity. The ethyl acetate extract yielded components that had an $\mathrm{Rf}$ value of 0.37 , which is similar to the $\mathrm{Rf}$ value of actinomycin-D (Sousa et al., 2002). Actinomycin-D, produced by S. parvulus, is a potent antineoplastic drug molecule and is used to inhibit cell proliferation in tumor cells (Rahman et al., 2010). Moreover, several studies report that most antibacterial compounds produced by the genus Streptomyces detected by bioautography method have Rfs similar to those found in our study (Hozzein et al., 2011; Krishnaveni et al., 2011). Purification of these antibiotics may further elucidate whether this antibiotic is a new bioactive metabolite, or has already been described in the literature.

Chemical prospection is generally performed with extracts from medicinal plants to identify compounds with therapeutic potential. Flavonoids, alkaloids, triterpenes, sesquiterpenes, tannins, and lignans have been extensively studied and found to possess these properties. Studies have reported the presence of these and other active compounds in various plants, in both plant and root extracts (Lôbo et al., 2010). Thus, it is important to consider that the rhizosphere has a high concentration of organic nutrients derived from the roots, influencing microorganisms to produce similar compounds (Melo and Azevedo, 2008).

Our results indicated the huge potential of species of $S$. parvulus as a useful and powerful source for the production of bioactive natural compounds owing to the production of metabolites with antimicrobial activity against multidrug-resistant bacteria. The literature has little information about this microorganism, which makes our study pioneering in this matter, since this actinobacteria produces bioactive metabolites with activity against Gram-positive and multi-drug resistant microorganisms.

\section{ACKNOWLEDGMENTS}

Research supported by Foundation for Science and Technology of the State of Pernambuco, process \#IBPG-0872-2.12/10. 


\section{REFERENCES}

Arasu MV, Duraipandiyan V, Agastian P and Ignacimuthu S (2009). In vitro antimicrobial activity of Streptomyces spp ERI-3 isolated from western Ghats rock soil (India). J. Mycol. Med. 19: 22-28. http://dx.doi.org/10.1016/j.mycmed.2008.12.002

Bauer AW, Kirby WM, Sherris JC and Turck M (1966). Antibiotic susceptibility testing by a standardized single disk method. Am. J. Clin. Pathol. 45: 493-496.

Berg $G$ and Smalla K (2009). Plant species and soil type cooperatively shape the structure and function of microbial communities in the rhizosphere. FEMS Microbiol. Ecol. 68: 1-13. http://dx.doi.org/10.1111/j.1574-6941.2009.00654.x

Choi HJ, Kim DW, Choi YW, Lee YG, et al. (2012). Broad-spectrum in vitro antimicrobial activities of Streptomyces sp strain BCNU 100. Biotechnol. Bioprocess Eng.; BBE 17: 576-583. http://dx.doi.org/10.1007/s12257-011-0151-2

CLSI (Clinical and Laboratory Standards Institute) (2014). Performance Standards for Antimicrobial Susceptibility Testing: Twenty-fourth Informational (Supplement): M100-S24.

Gorlach-Lira K and Coutinho HDM (2007). Population dynamics and extracellular enzymes activity of mesophilic and thermophilic bacteria isolated from semi-arid soil of northeastern Brazil. Braz. J. Microbiol. 38: 135-141. http://dx.doi. org/10.1590/S1517-83822007000100028

Goodfellow M, Kämpfer P, Busse HJ, Trujillo M, et al. (2012). Bergey's Manual of Systematic Bacteriology. 2nd edn. Vol 5. The Actinobacteria, Springer, New York.

Harbone JB (1998). In: Phytochemical methods: a guide to modern techniques of plant analysis (Harbone JB, ed). Chapman and Hall, New York.

Higginbotham SJ and Murphy CD (2010). Identification and characterisation of a Streptomyces sp. isolate exhibiting activity against methicillin-resistant Staphylococcus aureus. Microbiol. Res. 165: 82-86. http://dx.doi.org/10.1016/j. micres.2008.12.004

Hozzein WN, Rabie W and Ali MIA (2011). Screening the Egyptian desert actinobacteria as candidates for new antimicrobial compounds and identification of a new desert Streptomyces strain. Afr. J. Biotechnol. 10: 2295-2301.

Ichikawa T, Date M, Ishikura T and Ozaki A (1971). Improvement of kasugamycin-producing strain by the agar piece method and the prototroph method. Folia Microbiol. (Praha) 16: 218-224. http://dx.doi.org/10.1007/BF02884210

Kawamura T, Tago K, Beppu T and Arima K (1976). Antiviral antibiotic S15-1. Taxonomy of the producing strain and study of conditions for production of the antibiotic. J. Antibiot. 29: 242-247. http://dx.doi.org/10.7164/antibiotics.29.242

Khieu TN, Liu MJ, Nimaichand S, Quach NT, et al. (2015). Characterization and evaluation of antimicrobial and cytotoxic effects of Streptomyces sp. HUST012 isolated from medicinal plant Dracaena cochinchinensis Lour. Front. Microbiol. 6: 574.

Krishnaveni J, Radzom M, Zeeck A and Kishan V (2011). Taxonomy, fermentation, biological activities, isolation and characterization of metabolites obtained from a new strain of Streptomyces noursei (KC46). Int. J. Syst. Bacteriol. 10: 212-218.

Laidi RF, Sifour M, Sakr M and Hacene H (2008). A new actinomycete strain SK4-6 producing secondary metabolite effective against methicillin-resistant Staphylococcus aureus. World J. Microbiol. Biotechnol. 24: 2235-2241. http://dx.doi. org/10.1007/s11274-008-9735-1

Lôbo KMS, Athayde ACR, Silva AMA, Rodrigues FFG, et al. (2010). Evaluation of antibacterial activity and phytochemical prospection of Solanum paniculatum Lam. and Operculina hamiltonii (G. Don) D. F. Austin \& Staples from the semi-arid region of Paraíba State, Brazil. Rev. Bras. Plantas Med. 12: 227-233. http://dx.doi.org/10.1590/S1516$\underline{05722010000200016}$

Lyra FDA, Gonçalves de Lima O, Coelho JSB, Albuquerque MMF, et al. (1964). Ciclamicina e ciclacidina, Dois novos Antibióticos Produzidos pelo Streptomyces capoamus nov. sp. An. Acad. Bras. Cienc. 36: 323-334.

Madigan MT, Stahl DA, David P, Clark DP, et al. (2012). Brock Biology of Microorganisms, 13th edn. Benjamin-Cummings Publishing Company.

Manimaran M, Gopal JV and Kannabiran K. (2015) Antibacterial activity of Streptomyces sp VITMK1 isolated from mangrove soil of Pichavaram, Tamil Nadu, India. PNAS India Section B: Biological Sciences 1-8.

Matsuura T (2004). Caracterização taxonômica de actinomicetos endofíticos produtores de antibióticos isolados de cupuaçuzeiro (Theobroma grandiflorum Schum). Doctoral thesis. Universidade Estadual de Campinas, Campinas.

Melo IS and Azevedo JL (2008). Microbiologia Ambiental. 2nd edn. Embrapa Meio Ambiente, Jaguariúna.

Metz H (1961). Thin-layer chromatography for rapid assays of enzymic steroid transformations. Naturwissenschaften 48: 569570. http://dx.doi.org/10.1007/BF00589718

Nomomura $\mathrm{H}$ and Ohara Y (1969a). Distribution of actinobacteria in soil. VI. A culture method effective for both preferencial isolation and enumeration of Microbiospora and Streptosporangium strains in soil (Part 1). J. Ferment. Technol. 47: 463-469.

Nomomura H and Ohara Y (1969b). Distribution of actinobacteria in soil. VII. A culture method effective for both preferential isolation and enumeration of Microbiospora and Streptosporangium strains in soil. (Part 2). Classification of the isolates. J. Ferment. Technol. 47: 701-709. 
Pfefferle C, Theobald U, Gürtler H and Fiedler H (2000). Improved secondary metabolite production in the genus Streptosporangium by optimization of the fermentation conditions. J. Biotechnol. 80: 135-142. http://dx.doi.org/10.1016/ S0168-1656(00)00249-2

Raja A and Prabakarana P (2011). Actinobacteria and drug - an overview. Am. J. Drug Discov. Dev. 1: 74-84.

Rahman MDA, Islam MZ, Khondkar P and Islam MA (2010). Characterization and antimicrobial activities of a polypeptide antibiotic isolated from a new strain of Streptomyces parvulus. Bangladesh Pharm. J. 13: 14-17.

Robertson EAH, Cartwright RA and Oldschool M (1956). Phenolic substances of manufactured tea. I. Fractionation and paper chromatography of water-soluble substances. J. Sci. Food Agric. 8: 72-80. http://dx.doi.org/10.1002/jsfa.2740080203

Sanchez S and Demain AL (2002). Metabolic regulation of fermentation processes. Enzyme Microb. Technol. 31: 895-906. http://dx.doi.org/10.1016/S0141-0229(02)00172-2

Scher JM, Speakman JB, Zapp J and Becker H (2004). Bioactivity guided isolation of antifungal compounds from the liverwort Bazzania trilobata (L.) S.F. Gray. Phytochemistry 65: 2583-2588. http://dx.doi.org/10.1016/j.phytochem.2004.05.013

Sharma OP and Darwra RK (1991). Thin layer chromatographic separations of lantadenes, the pentacyclic triterpenoids from lantana (Lantana camara) plant. J. Chromatog. 567: 351-354. http://dx.doi.org/10.1016/0021-9673(91)85183-G

Shirling EB and Gottlieb D (1966). Methods for characterization of Streptomyces species. Int. J. Syst. Bacteriol. 16: $313-340$. http://dx.doi.org/10.1099/00207713-16-3-313

Sousa MFVQ, Lopes CE and Pereira N (2002). Development of a bioprocess for the production of actinomycin-D. Braz. J. Chem. Eng. 19: 277-285. http://dx.doi.org/10.1590/S0104-66322002000300002

Sokal RR and Rohlf FJ (1995). Biometry: the principles and practice of statistics in Biological research. W.H. Freeman, San Francisco.

Staneck JL and Roberts GD (1974). Simplified approach to identification of aerobic actinomycetes by thin-layer chromatography. Appl. Microbiol. 28: 226-231.

Trabulsi LR and Alterthum F (2008). Microbiologia. 5th edn. Editora Atheneu, São Paulo.

Vasconcelos NM, Fontes JM, Lins MRCR, Bernardo GRB, et al. (2015). Streptomyces ansochromogenes Tur-10 produces a substance with antifungal bioactivity. Genet. Mol. Res. 14: 5435-5444. http://dx.doi.org/10.4238/2015.May.22.13

Vasconcellos RLF, Silva MCP, Ribeiro CM and Nogueira Cardoso EJBN (2010). Isolation and screening for plant growthpromoting (PGP) actinobacteria from Araucaria angustifolia rhizosphere soil. Sci. Agric. 67: 743-746. http://dx.doi. org/10.1590/S0103-90162010000600019

Velho-Pereira S and Kamat NM (2011). Screening of actinobacteria for antimicrobial activities by a modified "Cross-Streak" method. Indian J. Pharm. Sci. 73: 223-228. http://dx.doi.org/10.4103/0250-474X.91566

Vimal V, Rajan BM and Kannabiran K (2009). Antimicrobial activity of marine Actinomycete, Nocardiopsis sp VITSVK 5 (FJ973467). Asian J. Med. Sci. 1: 57-63.

Wagner $\mathrm{H}$ and Bladt S (1996). Plant drug analysis - a thin layer chromatography atlas. Springer, Munich.

Weisburg WG, Barns SM, Pelletier DA and Lane DJ (1991). 16S ribosomal DNA amplification for phylogenetic study. J. Bacteriol. 173: 697-703.

Zhao XQ, Jiao WC, Jiang B, Yuan WJ, et al. (2009). Screening and identification of actinobacteria from marine sediments: investigation of potential producers for antimicrobial agents and type I polyketides. World J. Microbiol. Biotechnol. 25: 859-866. http://dx.doi.org/10.1007/s11274-009-9964-y 